\title{
DYNAMICS OF 137CS CONCENTRATIONS IN CHILDREN RESIDING IN THE RAIONS OF KYIV REGION BORDERING ON THE CHORNOBYL EXCLUSION ZONE \\ DubovaN.F., Bandazhevskyi Yu.I.
}

\section{ДИНАМІКА ВМІСТУ РАДІОНУКЛІДІВ 137СS В ОРГАНІЗМІ ДІТЕЙ ІЗ РАЙОНІВ КИївСЬКОї ОБЛАСТІ, ЩО МЕЖУЮТЬЬ З ЧОРНОБИЛЬСЬКОЮ ЗОНОЮ ВІДЧУЖЕННЯ}

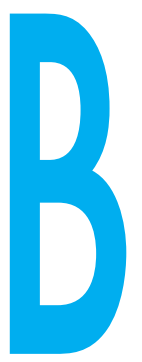

1ДУБОВА Н.Ф., 2БАНДАЖЕВСЬКИЙ Ю.І.

1 Національна

медична академія післядипломної освіти ім. П.Л. Шупика МОЗ України, м. Київ

2Координаційний аналітичний центр «Екологія і здоров'я», м. Іванків, Україна ід моменту катастрофи на Чорнобильській AEC одним 3 важливих завдань, що вирішуються при подоланні її наслідків, є зниження хронічного опромінення у населення радіоактивно забруднених територій (РЗТ). Для цього необхідний постійний контроль над надходженням радіонуклідів до організму жителів цих територій, особливо дітей і підлітків, які мають більш високу радіочутливість.

Київська область - одна з найбільш потерпілих від аварії на Чорнобильській атомній електростанції (ЧАЕС) за площею РЗТ, щільністю випадінь радіонуклідів на ґрунт та за кількістю потерпілих населених пунктів (НП) [1]. До організму їхніх мешканців радіоактивні речовини надходять переважно з продуктами харчування місцевого походження і виробництва.

При цьому найбільший внесок у формування внутрішньої дози опромінення робить ${ }^{137} \mathrm{Cs}$, внесок радіонукліда $90 \mathrm{Sr}$ найчастіше не перевищує 5\%, а радіонуклідів плутонію - 1\% [2].

Вимірювання інкорпорованого радіоцезію проводилося в Україні щорічно від 1986 року у населених пунктах найбільш потерпілих територій згідно 3 «Методичними рекомендаціями щодо проведення вимірювань з використанням ЛВЛ при дозиметричній паспортизації населених пунктів України» [3, 4]. Після 2012 року державна програма «Дозиметричної паспортизації населених пунктів України» та радіологічний моніторинг населення на РЗТ України перестали фінансуватися і припинилися.

Як показав багаторічний ЛВЛмоніторинг у Київській області,
ДИНАМІКА ВМІСТУ РАДІОНУКЛІДІВ ${ }^{137} \mathrm{Cs}$ В ОРГАНІЗМІ ДІТЕЙ ІЗ РАЙОНІВ КИЇВСЬКОЇ

ОБЛАСТІ, ЩО МЕЖУЮТЬ

З ЧОРНОБИЛЬСЬКОЮ ЗОНОЮ ВІДЧУЖЕННЯ 1 Дубова Н.Ф., 2 Бандажевський Ю.І.

1 Національна медична академія

післядипломної освіти ім. П.Л. Шупика,

МОЗ України, м. Київ, Україна

2Координаційний аналітичний центр

«Екологія і здоров'я», м. Іванків, Україна

Нинішня радіаційно-екологічна ситуація у найбільш потерпілих від аварії на Чорнобильській атомній електростанції районах Київської області свідчить про необхідність продовження моніторингу рівнів радіоактивного забруднення продуктів харчування лісового походження, а також вмісту інкорпорованого ${ }^{137} \mathrm{Cs}$ y жителів цих територій. Пріоритетною контрольованою групою має стати дитяче населення через більш високу радіочутливість. Мета дослідження: проаналізувати динаміку вмісту радіонуклідів ${ }^{137} \mathrm{Cs}$ в організмі дітей, які проживають в Іванківському та Поліському районах Київської області, з урахуванням віку та статі, а також з урахуванням реалізації програми протирадіаційної безпеки, передбаченої проектом Європейської Комісії.

Матеріали та методи. Радіометричний, математико-статистичний методи.

Результати. За 2014-2017 роки було проведено 10392 СВЛ-вимірювання у детей віком 018 років. Випадки з відносно низькими значеннями медіан питомої активності ${ }^{137} \mathrm{Cs}$ в організмі становили у середньому 95,0\% у групах хлопчиків та дівчаток. До критичної групи увійшли діти з рівнем радіоцезію в організмі понад 5, О Бк/кг. Найбільші рівні вмісту ${ }^{137} \mathrm{Cs}$ в організмі дітей реєструвались у жовтні-січні, тобто у період інтенсивної заготовки та споживання грибів. У динаміці за 2014-2017 роки вірогідно високу питому активність радіоцезію виявлено у дітей віком 6,0-11,0 років порівняно з віковою групою 12, 0-18,0 років. Максимальне значення питомої активності ${ }^{137} \mathrm{Cs}$ в організмі дитини $(307,29$ БК/Кг) зареєстровано у 2014-2015 роках.

Поінформування населення Іванківського та Поліського районів з питань протирадіаційної безпеки дозволило зменшити в обстеженій групі дітей питому вагу випадків вмісту радіонуклідів ${ }^{137} \mathrm{Cs}$ в організмі (понад 5, 0 Бк/кг) у два рази.

Ключові слова: СВЛ-вимірювання, діти, інкорпорований радіоцезій, радіоактивне забруднення, аварія на Чорнобильській АEC. 
DYNAMICS OF ${ }^{137}$ CS CONCENTRATIONS

IN CHILDREN RESIDING IN THE RAIONS

OF KYIV REGION BORDERING ON THE

CHORNOBYL EXCLUSION ZONE

1 DubovaN.F., 2 Bandazhevskyi Yu.I.

${ }^{1}$ National P.L. Shupyk Medical Academy

of Postgraduate Education, Ministry of Public

Health of Ukraine, Kyiv, Ukraine

${ }^{2}$ Ecology and Health Coordination and Analytical Centre, Ivankiv, Ukraine

The current radiation and environmental situation in the raions of Kyiv region the most affected the Chornobyl nuclear power plant accident indicates that there is a necessity to continue monitoring levels of radioactive contamination of foods of forest origin, as well as incorporated ${ }_{137} \mathrm{Cs}$ concentrations in the residents of these areas. The children's population have a higher radiosensitivity and it should be the prior monitored group.

Objective: We analyzed the dynamics of $137 \mathrm{Cs}$ concentrations in children residing in Ivankiv and Polissia raions, Kyiv region, taking into account their age and gender and the implementation of the radiation safety programme foreseen by the European Commission project.

Material and methods: Radiometric, mathe- matical and statistical methods.

Results: 10,392 SHI measurements of radionuclide levels in children aged $0-18$ years old were conducted during 2014-2017. Cases with relatively low median values for ${ }^{137}$ Cs specific activity in the organism was an average of $95.0 \%$, including in the groups of boys and girlsThe critical group included children with radiocaesium levels over $5.0 \mathrm{~Bq} / \mathrm{kg}$. The highest concentrations of ${ }^{137} \mathrm{Cs}$ in children were reported in October-January, i.e. during the period of intensive harvesting and consumption of mushrooms. In dynamicsof 2014-2017, the probably high specific activity of radiocaesium was found in the children aged 6.0-11.0 years old in comparison with the age group of 12.0-18.0 years old. The maximum value of ${ }^{137} \mathrm{Cs}$ specific activity in a child's organism (307.29 Bq/kg) was recorded in 2014-2015. Informing the population of Ivankiv and Polissia raions on radiation safety allowed to have the proportion of ${ }^{137} \mathrm{Cs}$ radionuclides in the organism (over $5.0 \mathrm{~Bq} / \mathrm{kg}$ ) in the examined group of children.

\section{Keywords: SHI measurements, children, incorporated radiocaesium, radioactive contamination, Chornobyl nuclear power plant accident.}

зокрема в Іванківському та Поліському районах, що межують з Чорнобильською зоною відчуження, $€$ низка НП, де дози внутрішнього опромінення населення залишаються нестабільними і варіюють 3 року в рік у широких межах, що може бути як наслідком різноманітності радіоекологічних і соціально-демографічних умов проживання, так і внутрішніх закономірностей поведінки, харчових звичок конкретних жителів. Ця ситуація вимагає продовження постійного радіологічного контролю, вивчення факторів такої нестабільності, а також розробки рекомендацій щодо мінімізації їхнього впливу [5].

За увесь період спостережень найчисленнішою групою обстежених було доросле населення. Питома вага дітей у середньому склала 40\% від усіх вимірювань вмісту радіоцезію в організмі по аналізованих районах [5].

у рамках проекту Європейської Комісії в Україні «Оздоровчі та екологічні програми, пов'язані 3 Чорнобильською зоною відчуження. Підготовка, навчання і координація проектів 3 охорони здоров'я» (2013-2017) було створено карту забруднення ${ }^{137} \mathrm{Cs}$ та ${ }^{90} \mathrm{Sr}$ території Іванківського району, щорічно проводилися вимірювання питомої активності ${ }^{137} \mathrm{Cs}$ в організмі усього дитячого населення Іванківського і Поліського районів, використовуючи стаціонарні спектрометри випромінювання людини (СВЛ). При цьому було реалізовано програму протирадіаційної безпеки дітей і дорослих, що передбачає радіаційний контроль продуктів харчування та інформаційне забезпечення населення [6].

\section{Таблиця 1 \\ Результати перевірки вибірки СВЛ-вимірювань дитячого населення на нормальність розподілу за критерієм Колмогорова-Смирнова за 2014-2017 роки}

\begin{tabular}{|l|c|c|c|c|}
\hline \multicolumn{2}{|c|}{ Параметр } & \multicolumn{3}{|c|}{$137 \mathrm{Cs}$, Бк/к } \\
\hline \multirow{2}{*}{$\begin{array}{l}\text { Обидві } \\
\text { статі }\end{array}$} & Період обстеження & $\mathrm{I}$ & $\mathrm{II}$ & $\mathrm{III}$ \\
\cline { 2 - 5 } & Кількість вимірювань & 3736 & 3423 & 3233 \\
\cline { 2 - 5 } & Ссимптотична значимість (2-стороння), $\mathrm{p}^{\star *}$ & 0,0001 & 0,0001 & 0,0001 \\
\hline \multirow{2}{*}{$\begin{array}{l}\text { Хлоп- } \\
\text { чики }\end{array}$} & Кількість вимірювань & 1861 & 1714 & 1617 \\
\cline { 2 - 5 } & Статистика критерію & 0,425 & 0,425 & 0,353 \\
\hline \multirow{2}{*}{$\begin{array}{l}\text { Дів- } \\
\text { чатка }\end{array}$} & Асимптотична значимість (2-стороння), & 0,0001 & 0,0001 & 0,0001 \\
\cline { 2 - 5 } & Кількість вимірювань & 1875 & 1709 & 1616 \\
\cline { 2 - 5 } & Асимптотична значимість (2-стороння), & 0,0001 & 0,0001 & 0,0001 \\
\hline
\end{tabular}

Примітка. * - I (2014-2015), II (2015-2016), III (2016-2017);

** - відхилення від нормального розподілу вважається істотним за значення $p<0,05$, у цьому випадку для відповідних змінних слід застосовувати непараметричні тести.

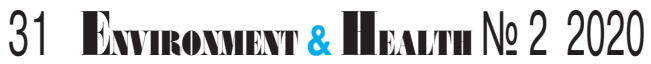


проживають в Іванківському та Поліському районах Київської області, що межують з Чорнобильською зоною відчуження.

Вимірювання питомої активності ${ }^{137} \mathrm{Cs}$ проводилося на 3-детекторному спектрометрі випромінювання людини «СИЧ-АКП-З», виготовле«АТОМКОМПЛЕКСПРИЛАД». ному в Україні ТОВ НВП

Час експозиції склав 10 хвилин. Спектрометр забезпечує точність вимірювання за вмісту $137 \mathrm{Cs}$ в організмі до 5 Бк/кг (похибка вимірювань не перевищує 30\%).

Прилади «СИЧ-АКП-З» встановлено у радіометричній лабораторії Іванківської центральної районної лікарні, де проводилася щорічна метро-

Таблиця 2

Кількість СВЛ-вимірювань, проведених у дитячого населення Іванківського і Поліського районів Київської області різних вікових груп залежно від періоду дослідження

\begin{tabular}{|l|c|c|c|c|c|c|}
\hline \multirow{2}{*}{$\begin{array}{c}\text { Період } \\
\text { вимірювань } \\
\text { роки }\end{array}$} & \multicolumn{5}{|c|}{ Кількість СВЛ-вимірювань } & \multirow{2}{*}{$\begin{array}{c}\text { у вікових групах (роки) } \\
\text { школярів }\end{array}$} \\
\cline { 2 - 6 } & $\begin{array}{c}\text { Усі вікові } \\
\text { групи }\end{array}$ & $0-2$ & $3-5$ & $6-11$ & $12-18$ & \\
\hline $2014-2015$ & 3736 & 11 & 237 & 1742 & 1746 & 93,4 \\
\hline $2015-2016$ & 3423 & 5 & 114 & 1745 & 1559 & 96,5 \\
\hline $2016-2017$ & 3233 & 7 & 229 & 1498 & 1499 & 92,7 \\
\hline Разом & 10392 & 23 & 580 & 4985 & 4804 & 94,2 \\
\hline
\end{tabular}

Результати статистичного аналізу індивідуальних показників питомої активності інкорпорованого ${ }^{137} \mathrm{Cs}$ у дітей із досліджуваних районів Київської області

\begin{tabular}{|c|c|c|c|c|c|}
\hline \multirow{2}{*}{$\begin{array}{c}\text { Період } \\
\text { вимірювань, } \\
\text { роки }\end{array}$} & \multirow{2}{*}{$\begin{array}{l}\text { Кількість } \\
\text { дітей }\end{array}$} & \multicolumn{4}{|c|}{ Рівень вмісту в організмі ${ }^{137} \mathrm{Cs}$, Бк·кг-1 } \\
\hline & & Медіана & IKP & $\begin{array}{c}90- \\
\text { квантиль }\end{array}$ & $\begin{array}{c}\text { Максимальне } \\
\text { значення }\end{array}$ \\
\hline \multicolumn{6}{|c|}{ Обидві статі } \\
\hline 2014-2015 & 3736 & 2,09 & $1,64-2,62$ & 3,23 & 307,29 \\
\hline $2015-2016$ & 3423 & 2,05 & $1,63-2,54$ & 2,92 & 199,38 \\
\hline 2016-2017 & 3233 & 2,04 & $1,63-2,54$ & 2,91 & 77,33 \\
\hline \multicolumn{6}{|c|}{ Хлопчики } \\
\hline $2014-2015$ & 1861 & 2,14 & $1,65-2,63$ & 3,34 & 307,29 \\
\hline $2015-2016$ & 1714 & 2,08 & $1,64-2,54$ & 2,90 & 199,38 \\
\hline $2016-2017$ & 1617 & 2,06 & $1,66-2,54$ & 2,87 & 45,82 \\
\hline \multicolumn{6}{|c|}{ Дівчатка } \\
\hline $2014-2015$ & 1875 & 2,02 & $1,63-2,61$ & 3,14 & 126,4 \\
\hline $2015-2016$ & 1709 & 2,00 & $1,62-2,54$ & 2,94 & 118,51 \\
\hline 2016-2017 & 1616 & 2,02 & $1,62-2,53$ & 2,93 & 77,33 \\
\hline
\end{tabular}

Результати порівняння питомої активності $137 \mathrm{Cs}$ в організмі дітей, обстежених у різні роки проведення скринінгу, за допомогою непараметричного

\section{U-критерію Манна-Уїтні}

\begin{tabular}{|c|c|c|c|c|}
\hline \multirow{2}{*}{$\begin{array}{l}\text { Показ- } \\
\text { ник }\end{array}$} & \multirow{2}{*}{$\begin{array}{c}\text { Періоди } \\
\text { порівняння }\end{array}$} & \multicolumn{3}{|c|}{$\begin{array}{c}\text { Значення U-критерію Манна-Уїтні, } \\
\text { рівень значущості р }\end{array}$} \\
\hline & & Загальна група & Хлопчики & Дівчатка \\
\hline \multirow{3}{*}{ 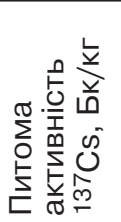 } & & $\begin{array}{l}U=61098 \\
p=0,0\end{array}$ & $\begin{array}{r}U=1 \\
p=\end{array}$ & $\begin{array}{l}U=15 \\
p=\end{array}$ \\
\hline & & $\begin{array}{l}U=5761112,0 \\
p=0,001\end{array}$ & $\begin{array}{l}U=14 \\
p=(\end{array}$ & $\begin{array}{c}U=145 \\
p=\end{array}$ \\
\hline & & $\begin{array}{l}U=5525193,0 \\
p=0,918\end{array}$ & $\begin{array}{l}U=1381 \\
p=0\end{array}$ & $\begin{array}{l}U=1379122,0 \\
\quad p=0,950\end{array}$ \\
\hline
\end{tabular}

Примітка до таблиць 4 і 6 :

* - I (2014-2015), II (2015-2016), III (2016-2017). логічна повірка їх. Регулярне обслуговування і тестування приладів здійснюється фірмою-виробником. Для автоматичної обробки спектрів, розрахунку питомої активності радіоактивних елементів і збереження отриманої інформації використовувалося програмне забезпечення приладу «AKWin». Відповідно до Наказу МОЗ України від 14.02.2012 [7] радіометричне і антропометричні обстеження дітей, а також обробка їхніх персональних даних було проведено за згодою батьків.

Статистична обробка отриманих результатів здійснювалася за допомогою програми IBM SPSS Statistics 22 (США). Для показників, що аналізувалися, розраховувалися медіана (Me), інтерквартильний розмах (IKP), мінімальні і максимальні значення параметрів, процентилі. Було проведено перевірку гіпотези про вид розподілу (критерій Колмогорова-Смирнова). Результати перевірки вибірки на нормальність розподілу та підтвердження можливості використання непараметричних методів статистики наведено у таблиці 1. Критичний рівень достовірності нульової статистичної гіпотези (p) прийнято за 0,05 .

Результати досліджень. За період з 2014 по 2017 рік радіометричне обстеження пройшло 10392 дітей, у середньому 3464 осіб на рік.

Основну масу обстежених становили діти шкільного віку (6,0-18,0 років), питома вага дошкільнят варіювала від 3,5\% до 7,3\% залежно від періоду дослідження (табл. 2). Зважаючи на переважання школярів серед обстежених дітей радіологічні вимірювання проводилися відповідно до термінів проведення шкільних занять, тому період радіологічного обстеження починався у жовтні і закінчувався у травнічервні.

Аналіз узагальнених результатів СВЛ-вимірювань показав, що в організмі 93,0-6,0\% обстежених дітей реєструвалися відносно низькі значення медіан питомої активності ${ }^{137 C s,}$ у тому числі у групах хлопчиків і дівчаток (табл. 3). 


\section{ДИНАМИКА СОДЕРЖАНИЯ РАДИОНУКЛИДОВ 137СS В ОРГАНИЗМЕ ДЕТЕЙ, \\ ПРОЖИВАЮЩИХ В РАЙОНАХ КИЕВСКОЙ ОБЛАСТИ, ГРАНИЧАЩИХ С ЧЕРНОБЫЛЬСКОЙ ЗОНОЙ ОТЧУЖДЕНИЯ \\ 1 Дубовая Н.Ф., 2 Бандажевский Ю.И. \\ 1 Национальная медицинская академия последипломного образования \\ им. П.Л. Шупика, МЗ Украины, Г. Киев \\ 2Координационный аналитический центр \\ «Экология и здоровье», г. Иванков, Украина}

Существующая радиационно-экологическая ситуация в наиболее пострадавших от аварии на Чернобыльской атомной электростанции районах Киевской области свидетельствует о необходимости продолжения мониторинга уровней радиоактивного загрязнения продуктов питания, особенно лесного происхождения, а также содержания инкорпорированного ${ }^{137} \mathrm{Cs}$ у жителей этих территорий. Приоритетной контролируемой группой должно стать детское население, имеющее более высокую радиочувствительность. Целью исследования было проанализировать динамику содержания радионуклидов 137Cs в организме детей, проживающих в Иванковском и Полесском районах Киевской области, с учетом возраста и пола, а также с учетом реализации программы противорадиационной безопасности, предусмотренной проектом Европейской Комиссии.
Материалы и методы. Радиометрический, математико-статистический.

Результаты. За 2014-2017 годы было проведено 10392 СИЧ-измерения у детей в возрасте 0-18 лет. Случаи с относительно низкими значениями медиан удельной активности ${ }^{137} \mathrm{Cs}$ в организме составили в среднем 95,0\% в группах мальчиков и девочек. В критическую группу были отнесены дети с уровнем радиоцезия в организме выше 5,0 Бк/Кг. Наибольшие уровни содержания ${ }^{137} \mathrm{Cs}$ в организме детей регистрировались в октябреянваре, т.е. в период интенсивной заготовки и потребления грибов. В динамике за 20142017 годы достоверно высокая удельная активность радиоцезия выявлена у детей в возрасте 6,0-11,0 лет по сравнению с возрастной группой 12,0-18,0 лет. Максимальное значение удельной активности ${ }^{137} \mathrm{Cs}$ в организме ребенка $(307,29$ Бк/Кг) зарегистрировано в 2014-2015 годах. Информирование населения Иванковского и Полесского районов по вопросам противорадиационной безопасности позволило уменьшить в обследуемой группе детей удельный вес случаев содержания радионуклидов ${ }^{137} \mathrm{Cs}$ в организме свыше 5,0 Бк/кг в два раза.

\section{Ключевые слова: СИЧ-измерения, дети, инкорпорированный радиоцезий, радиоактивное загрязнение, авария на Чернобыльской АЭС.}

Проте слід зазначити, що у період вимірювань (20142015) у групі хлопчиків було зареєстровано випадок, коли питома активність ${ }^{137} \mathrm{Cs}$ в організмі склала 307,29 Бк/кг. При цьому у групі дівчаток максимальне значення питомої активності ${ }^{137} \mathrm{Cs}$ в організмі було 126,4 Бк/кГ.

При вимірюванні у 20152016 роках максимальні значення питомої активності ${ }^{137} \mathrm{Cs}$ в організмі зареєстровано у групі хлопчиків на рівні 199,38 Бк/кг, у групі дівчаток - на рівні $118,51 \mathrm{БК/Кг.}$

у 2016-2017 роках максимальні значення питомої активності $137 \mathrm{Cs}$ в організмі виявлено у групі хлопчиків на рівні 45,82 Бк/кг, у групі дівчаток - на рівні 77,33 Бк/кг

Статистично підтверджено зниження вмісту радіонуклідів 137Cs в організмі дітей при вимірюванні у періоди 20152016 pp. i 2016-2017 pp., порівняно 3 періодом 20142015 рр. (табл. 3 і 4). Особливо чітко це представлене при виділенні груп дітей з показниками питомої активності ${ }^{137} \mathrm{Cs}$ в організмі понад 5,0 Бк/кг (табл. 5, 6). У перший рік вимірювань відносна кількість дітей 3 питомою активністю

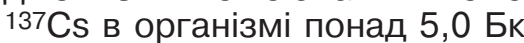
/кг була статистично більшою порівняно з наступними роками вимірювань (табл. 6).

Виявлення дітей з вмістом в організмі ${ }^{137} \mathrm{Cs}$ понад 5 Бк/кг (група підвищеного радіаційно-

го ризику) є важливим з кількох причин, і на них має бути звернена увага під час оцінки стану здоров'я і ролі радіаційного фактора. Ці діти мають бути об'єктом адресних захисних заходів щодо зниження опромінення. Крім того, виявлення закономірностей формування підвищеного вмісту радіоцезію

Таблиця 5

$$
\begin{gathered}
\text { Результати статистичного аналізу вмісту } \\
\text { інкорпорованого }{ }^{137} \mathrm{Cs} \text { (понад 5,0 Бк/кг) у дітей } \\
3 \text { досліджуваних районів Київської області }
\end{gathered}
$$

\begin{tabular}{|c|c|c|c|c|c|}
\hline $\begin{array}{c}\text { Період } \\
\text { вимірювань, } \\
\text { роки }\end{array}$ & \multirow{5}{*}{$\begin{array}{c}\text { Кількість } \\
\text { дітей }\end{array}$} & Медіана & ІКР & $\begin{array}{c}\text { 90\%- } \\
\text { квантиль }\end{array}$ & $\begin{array}{c}\text { Максимальне } \\
\text { значення }\end{array}$ \\
\cline { 3 - 6 } Обидві статі \\
\hline $2014-2015 Д$ & 267 & 13,5 & $9,03-23,81$ & 50,75 & 307,29 \\
\hline $2015-2016$ & 155 & 11,5 & $8,43-17,81$ & 29,92 & 199,38 \\
\hline $2016-2017$ & 119 & 10,2 & $7,75-15,5$ & 25,39 & 77,33 \\
\hline \multicolumn{5}{|c|}{ Хлопчики } \\
\hline $2014-2015$ & 149 & 12,5 & $8,87-25,0$ & 59,5 & 307,29 \\
\hline $2015-2016$ & 83 & 11,5 & $8,56-19,80$ & 45,29 & 199,38 \\
\hline $2016-2017$ & 64 & 10,2 & $7,68-14,7$ & 25,33 & 45,82 \\
\hline \multicolumn{5}{|c|}{ Дівчатка } \\
\hline $2014-2015$ & 118 & 14,4 & $9,41-23,2$ & 41,6 & 126,4 \\
\hline $2015-2016$ & 72 & 11,4 & $8,40-14,55$ & 29,04 & 118,51 \\
\hline $2016-2017$ & 55 & 10,2 & $7,84-16,0$ & 31,6 & 77,3 \\
\hline
\end{tabular}


в організмі у цих дітей дозволить виробити критерії першочергового реагування у випадках можливих у майбутньому радіаційних аварій.

Аналіз результатів СВЛвимірювань протягом 20142015 років показав достовірно більший внесок хлопчиків порівняно з дівчатками у групу 3 вмістом ${ }^{137} \mathrm{Cs}$ в організмі понад 5,0 Бк/кг (табл. 8).

Вивченням вікових характеристик групи підвищеного радіаційного ризику (вміст

\section{Результати порівняння питомої активності $137 \mathrm{Cs}$} з рівнем понад 5,0 Бк/кг в організмі дітей, які досліджувались у різні роки проведення скринінгу за допомогою непараметричного U-критерію Манна-Уїтні

\begin{tabular}{|c|c|c|c|c|}
\hline \multirow{2}{*}{ Показник } & \multirow{2}{*}{$\begin{array}{c}\text { Періоди } \\
\text { порівняння* }\end{array}$} & \multicolumn{3}{|c|}{$\begin{array}{c}\text { Значення U-критерію Манна-Уїтні, } \\
\text { рівень значущості р }\end{array}$} \\
\hline & & Загальна група & Хлопчики & Дівчатка \\
\hline \multirow{3}{*}{$\begin{array}{l}\text { Питома } \\
\text { активність } \\
137 \mathrm{Cs}, \text { Бк/кг }\end{array}$} & I - II & $\begin{aligned} \mathrm{U} & =17520,0 ; p \\
& =0,009\end{aligned}$ & $\begin{array}{c}U=5708,5 \\
p=0,332\end{array}$ & $\begin{array}{c}U=3174,5 \\
p=0,004\end{array}$ \\
\hline & I - III & $\begin{aligned} U & =11543,5 ; p \\
& =0,0001\end{aligned}$ & $\begin{array}{c}U=3540,5 \\
p=0,003\end{array}$ & $\begin{array}{c}U=2286,0 \\
p=0,002\end{array}$ \\
\hline & II - III & $\begin{array}{l}U=8102,5 \\
p=0,085\end{array}$ & $\begin{array}{l}U=2165,5 \\
p=0,055\end{array}$ & $\begin{array}{c}U=1906,5 \\
p=0,721\end{array}$ \\
\hline
\end{tabular}

Розподіл СвЛ-вимірювань дітей із досліджуваних районів Київської області з різними рівнями інкорпорованого ${ }^{137}$ Cs в організмі у динаміці протягом 2014-2017 років

\begin{tabular}{|c|c|c|c|c|c|}
\hline \multirow{3}{*}{$\begin{array}{c}\text { Періоди } \\
\text { вимірювань, } \\
\text { роки }\end{array}$} & \multirow{3}{*}{$\begin{array}{c}\text { Кількість } \\
\text { досліджених } \\
\text { дітей }\end{array}$} & \multicolumn{4}{|c|}{$\begin{array}{l}\text { Кількість СВЛ-вимірювань з питомою } \\
\text { активністю }{ }^{137} \mathrm{Cs} \text { в організмі дітей }\end{array}$} \\
\hline & & \multicolumn{2}{|c|}{ менше 5,0 Бк/кг } & \multicolumn{2}{|c|}{ понад 5,0 Бк/кг } \\
\hline & & $\begin{array}{l}\text { Абс. } \\
\text { число }\end{array}$ & Питома вага & $\begin{array}{l}\text { Абс. } \\
\text { число }\end{array}$ & $\begin{array}{l}\text { Питома } \\
\text { вага }\end{array}$ \\
\hline $2014-2015^{\star}$ & 3736 & 3469 & $92,85 \pm 0,42$ & 267 & $7,15 \pm 0,42$ \\
\hline $2015-2016$ & 3423 & 3268 & $95,47 \pm 0,36$ & 155 & $4,53 \pm 0,36$ \\
\hline $2016-2017$ & 3233 & 3114 & 96,32 $\pm 0,33$ & 119 & $3,68 \pm 0,33$ \\
\hline \multicolumn{6}{|c|}{ Примітка: * - виявлені достовірні відмінності між питомою } \\
\hline
\end{tabular}

Розподіл дітей за статтю із досліджуваних районів

Київської області з рівнями інкорпорованого $137 \mathrm{Cs}$ в організмі понад 5,0 Бк/кг у динамиці за 2014-2017 роки

\begin{tabular}{|c|c|c|c|c|c|}
\hline \multirow{2}{*}{$\begin{array}{c}\text { Періоди } \\
\text { вимірювань } \\
\text { роки }\end{array}$} & \multirow{2}{*}{$\begin{array}{l}\text { Кількість } \\
\text { дітей }\end{array}$} & \multicolumn{2}{|c|}{ Хлопчики } & \multicolumn{2}{|c|}{ Дівчатка } \\
\hline & & $\begin{array}{c}\text { Кількість } \\
\text { дітей }\end{array}$ & $\begin{array}{c}\text { Питома } \\
\text { вага }\end{array}$ & $\begin{array}{c}\text { Кількість } \\
\text { дітей }\end{array}$ & $\begin{array}{c}\text { Питома } \\
\text { вага }\end{array}$ \\
\hline $2014-2015^{\star}$ & r & 149 & $55,8 \pm 3,04$ & 118 & $44,2 \pm 3,04$ \\
\hline $2015-2016$ & 155 & 83 & $53,6 \pm 4$ & 72 & $46,5 \pm 4,01$ \\
\hline $2016-2017$ & 119 & 64 & $53,8 \pm 4,57$ & 55 & $46,2 \pm 4,57$ \\
\hline
\end{tabular}

Примітка: * - виявлені достовірні відмінності між питомою вагою хлопчиків і дівчаток з вмістом 137 Cs в організмі понад 5, О Бк/кг під час СВЛ-скринінгу у 2014-2015 роках $(t=2,7 ; p=0,007422)$. дітей підвищеного радіаційного ризику і провести їх анкетування з метою вивчення особливостей раціону харчування. У разі виявлення радіаційним контролем підвищеного вмісту $137 \mathrm{Cs}$ в організмі дитини усім членам родини рекомендувалося пройти контроль на СВЛустановці. Для з'ясування джерела забруднення радіонуклідами організму дитини батькам пропонувалося принести на дослідження найбільш вживані родиною продукти харчування: молоко, картоплю, овочі, фрукти, гриби, ягоди тощо.

Підсумки опитування показали, що діти віком 6,0-11,0 років з більшою частотою споживали молочні продукти місцевого походження порівняно з групою дітей віком 12,0-18,0 років $[8,9]$.

Аналіз сезонного розподілу результатів СВЛ-вимірювань у дітей 3 рівнем вмісту ${ }^{137} \mathrm{Cs}$ в організмі понад 5,0 Бк/кг виявив більш високі значення медіани у жовтні, листопаді, грудні і січні - періодах інтенсивної заготівлі та споживання грибів (рис. 1).

Отримані результати свідчать про присутність радіаційного чинника у довкіллі та організмі дітей досліджуваних районів через багато років після аварії на ЧАЕС. Зважаючи на здатність радіонуклідів $137 \mathrm{Cs}$ інкорпоруватися, навіть у відносно невеликих кількостях викликати пошкодження життєво важливих органів дитячого організму [10, 11], актуальним нині залишається питання протирадіаційної безпеки.

Фактичні дані про ступінь забруднення радіонуклідами дитячого населення і продуктів харчування можуть бути використані як потужний інформаційний потенціал у роботі місцевих центрів протирадіаційної безпеки.

у рамках проекту Європейської Комісії «Оздоровчі та екологічні програми, пов'язані з Чорнобильською зоною відчуження. Підготовка, навчання і координація проектів з охорони здоров'я» на базі Іванківської центральної районної лікарні було створено інформаційно-консультаційний центр з питань гігієни і харчу- 
вання, одним із завдань якого було проведення роз'яснювальної роботи серед населення Іванківського і Поліського районів щодо правил безпечної життєдіяльності на радіоактивно забрудненій території та ведення здорового способу життя. Особливий акцент було зроблено на проведенні радіологічного контролю продуктів місцевого виробництва та «дарів лісу»: ягід, грибів, а також м'яса диких тварин і риби. Різноманіття форм реалізації інформаційної роботи центру (рис. 2) 3 медичними працівниками, педагогами та батьками дозволили майже вдвічі скоротити частоту реєстрації серед дитячого контингенту випадків з рівнями питомої активності радіоцезію в організмі понад 5,0 Бк /кг (рис. 3 ).

Отримані результати свідчать про необхідність постійного проведення протирадіаційних заходів на території, що постраждала від аварії на Чорнобильській атомній електростанції. Окрім радіологічного контролю населення i продуктів харчування, вони мають передбачати інформаційну програму, а також проведення щорічних медичних обстежень дітей і підлітків.

\section{Висновки}

У віддалений період після аварії на Чорнобильській атомній електростанції на радіоактивно забруднених територіях актуальним залишається питання проникнення радіонуклідів ${ }^{137} \mathrm{Cs}$ в організм жителів, особливо дітей, про що свідчать результати прямих СВЛ-вимірювань. Найбільші рівні питомої активності ${ }^{137} \mathrm{Cs}$ в організмі дітей Іванківського і Поліського районів реєструвалися у жовтні-січні, тобто у період інтенсивної заготівлі та споживання грибів.

2. Порівняльний аналіз розподілу результатів СВЛ-вимірювань 3 урахуванням віку виявив достовірно більший вміст радіонуклідів ${ }^{137} \mathrm{Cs}$ в opганізмі дітей обох статей віком 6,0-11,0 років порівняно 3 дітьми віком 12,0-18,0 років у динаміці за 2014-2017 роки. Таким чином, діти молодшого шкільного віку піддаються більшому радіаційного впливу порівняно зі старшими дітьми.
Причиною цього явища може бути його тісніший зв'язок 3 продуктами харчування місцевого походження, передусім молоком корів.

Результати статистичного аналізу індивідуального вмісту інкорпорованого ${ }^{137} \mathrm{Cs}$ (понад 5,0 Бк/кг) у дітей із досліджуваних районів Київської області за віковими групами

\begin{tabular}{|c|c|c|c|c|c|}
\hline \multirow{2}{*}{$\begin{array}{c}\text { Періоди } \\
\text { вимірювань, } \\
\text { роки }\end{array}$} & Кількість & \multicolumn{5}{|c|}{ Рівень вмісту в організмі ${ }^{137} \mathrm{Cs}$, Бк·кг-1 } \\
\cline { 2 - 6 } & Ведіана & ІКР & $\begin{array}{c}\text { 90\%- } \\
\text { квантиль }\end{array}$ & $\begin{array}{c}\text { Максимальне } \\
\text { значення }\end{array}$ \\
\hline \multicolumn{6}{|c|}{ Вікова група дітей 6,0-11,0 років } \\
\hline $2014-2015$ & 60 & 18,4 & $13,3-28,0$ & 39,7 & 92,6 \\
\hline $2015-2016$ & 39 & 15,0 & $10,9-24,4$ & 38,2 & 59,8 \\
\hline $2016-2017$ & 30 & 15,9 & $11,6-24,7$ & 41,2 & 75,6 \\
\hline \multicolumn{7}{|c|}{ Вікова група дітей 12,0-18,0 років } \\
\hline $2014-2015$ & 207 & 11,7 & $8,44-22,0$ & 52,84 & 307,4 \\
\hline $2015-2016$ & 116 & 10,5 & $7,83-15,1$ & 26,36 & 118,5 \\
\hline $2016-2017$ & 89 & 9,01 & $7,61-13,5$ & 16,71 & 77,3 \\
\hline
\end{tabular}

Таблиця 10

Результати порівняння питомої активності $137 \mathrm{Cs}$ з вмістом понад 5,0 Бк/кг в організмі дітей різного віку, які пройшли СВЛ-вимірювання у 2014-2017 роках

\begin{tabular}{|c|c|c|c|c|c|}
\hline Показник & $\begin{array}{c}\text { Період } \\
\text { вимірю- } \\
\text { вання } \\
\end{array}$ & $\begin{array}{l}\text { Групи } \\
\text { порів- } \\
\text { няння }\end{array}$ & $\begin{array}{c}\text { Чисельність } \\
\text { групи } \\
\text { порівняння }\end{array}$ & $\begin{array}{c}\text { Середній } \\
\text { ранг }\end{array}$ & $\begin{array}{c}\text { Значення } \\
\text { U-критерію, рівень } \\
\text { значущості p }\end{array}$ \\
\hline \multirow{6}{*}{$\begin{array}{l}\text { Питома } \\
\text { активність } \\
\text { 137Cs, } \\
\text { Бк/кг }\end{array}$} & \multirow{2}{*}{ I } & $A$ & 60 & 164,33 & \multirow{2}{*}{$\begin{array}{c}U=4390,5 \\
p=0,001\end{array}$} \\
\hline & & B & 207 & 125,21 & \\
\hline & \multirow{2}{*}{ II } & $A$ & 39 & 100,51 & \multirow{2}{*}{$\begin{array}{l}U=1384,0 \\
p=0,0001\end{array}$} \\
\hline & & B & 116 & 70,43 & \\
\hline & \multirow{2}{*}{ III } & $A$ & 30 & 83,50 & \multirow{2}{*}{$\begin{array}{l}U=630,0 \\
p=0,0001\end{array}$} \\
\hline & & $B$ & 89 & 52,08 & \\
\hline
\end{tabular}

Примітка: * - I (2014-2015), II (2015-2016), III (2016-2017);

A - група дітей віком 6,0-11,0 років,

В - група дітей віком 12,0-18,0 років.

Сезонний розподіл результатів СВЛ-вимірювань у дітей з рівнем вмісту ${ }^{137} \mathrm{Cs}$ в організмі понад 5,0 Бк/кг

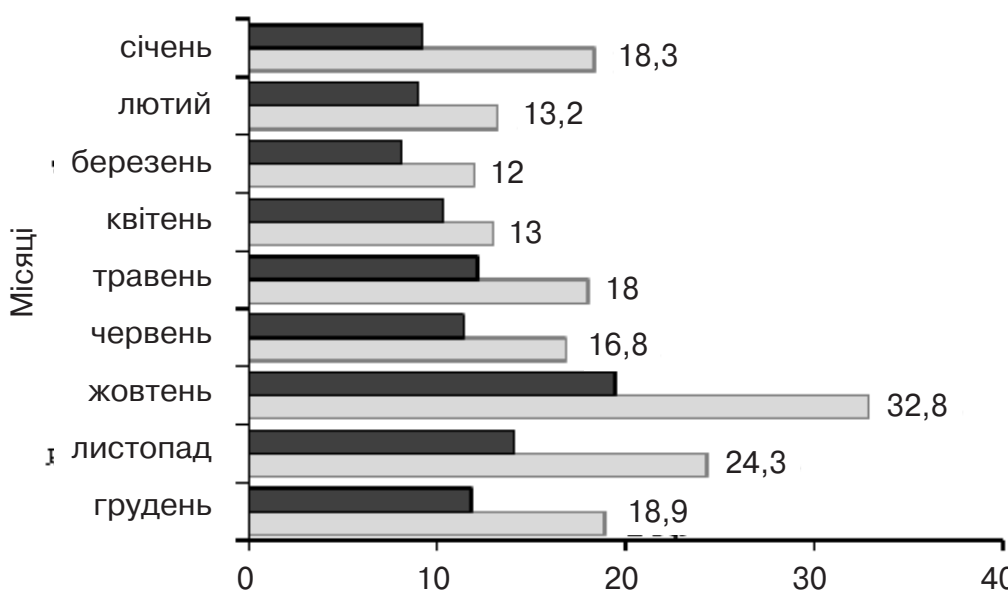

БК Кг 
3736) обстежених дітей у 2014-2015 роках зазнавали значного радіаційного впливу (максимальна питома активність ${ }^{137} \mathrm{Cs}$ в організмі дитини склала 307,29 Бк/кг).

4. Поінформування населення Іванківського і Поліського районів з питань протирадіаційної безпеки дозволило зменшити в обстежуваній групі дітей відносну кількість випадків вмісту радіонуклідів ${ }^{137} \mathrm{Cs}$ в організмі понад 5,0 Бк /кг від 7,2\% до 3,7\%.

5. Проведені дослідження свідчать про необхідність проведення нині на території, що постраждала від аварії на Чорнобильській атомній електростанції, протирадіаційних заходів, що передбачають радіологічний контроль населення і продуктів харчування, інформаційний блок і медичне обстеження дітей і підлітків.

\section{ЛІТЕРАТУРА}

1. 20 років Чорнобильської катастрофи. Погляд у майбутнє : Національна доповідь України. Київ : Атика, 2006. 232 с.

2. Радиационный мониторинг облучения населения в отдаленный период после аварии на Чернобыльской АЭС. Рабочие материалы ТС проект RER/9/074 «Стратегия долгосрочных мер защиты и мониторинг облучения населения сельских территорий, подвергшихся воздействию Чернобыльской аварии».

Вена, 2007. 119 с.

3. Перевозников О.Н., Литвинец Л.А., Яковлева Г.Н., Василенко В.В. Методические рекомендации по проведению измерений с использованием счетчиков излучения человека при дозиметрической паспортизации населенных пунктов Украины. Киев : ННЦРМ, 1995. 25 с.

Рисунок 2

Форми роботи інформаційно-консультаційного центру з гігієни і харчування 3 населенням Іванківського і Поліського районів

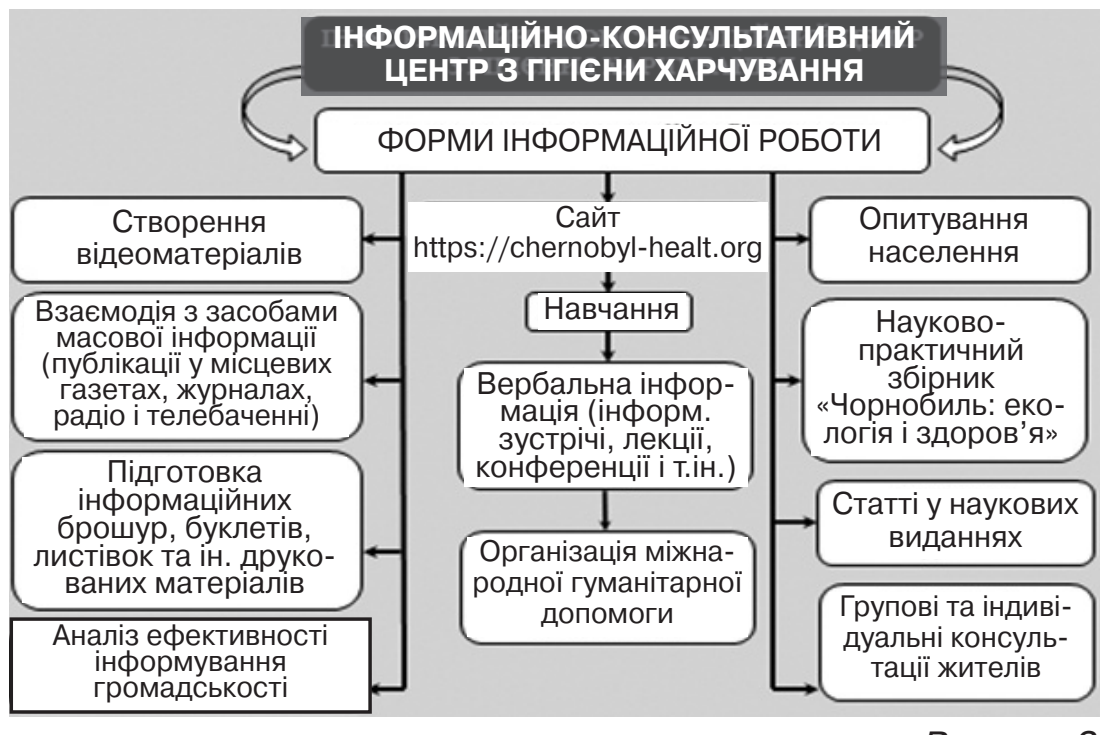

Структура результатів вимірювань з різними рівнями питомої активності 137Cs в організмі дітей (2014-2017)

2014-2015 $2015-2016$ 2016-2017
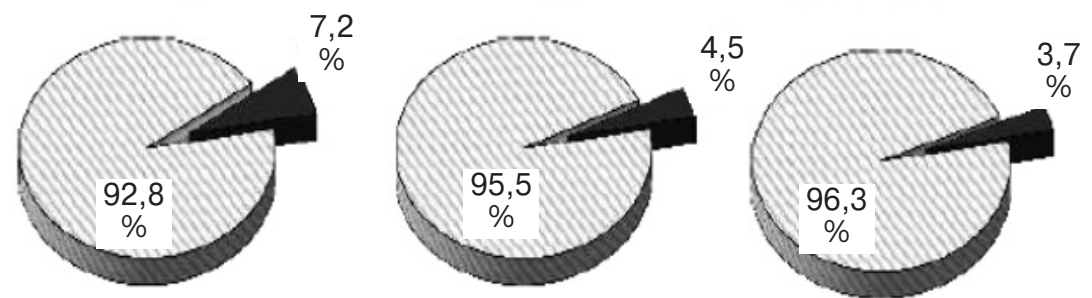

口.Менше 5,0 Бк/кг

п.Понад 5,0 Бк/кг
4. Нечаєв С.Ю., Василенко В.В., Перевозников О.М., Рубель Н.Ф., Піхта В.О.

Моніторинг доз внутрішнього опромінення населення на пізньому етапі аварії на ЧАЕС з використанням лічильників випромінювання людини : метод. рек. Київ, 2010. 24 с.

5. Василенко В.В., Масюк С.В., Іванова О.М. та ін. Результати ЛВЛ-вимірювань, проведених на радіоактивно забруднених територіях України у 1986-2014 рр. (ревізія та аналіз). Проблеми радіаційної медицини та радіобіології. 2018. Вип. 23. C. $120-137$.

6. Kadun O.N. Ivankov and Polessky districts implementation of socio-medical project of the European commission «Health and environmental programs round the Chornobyl exclusion zone». Collection of Scientific and Practical Articles "Chornobyl: ecology and health» / Under general editorship of Prof. Yu.I. Bandazhevsky. Issue 6. Ivankiv : PI Coordination and Analytical Center «Ecology and health». Dnipro : Seredniak T.K., 2017. P. 4-11.

7. Про затвердження форм первинної облікової документації та інструкцій щодо їх заповнення, що використовуються у закладах охорони здоров'я незалежно від форми власності та підпорядкування : Наказ МОЗ України 14.02.2012 № 110. URL : https://zakon.rada.gov.ua/laws /show/z0661-12

8. Бандажевский Ю.И., Дубовая Н.Ф., Кадун О.Н Возрастные особенности содержания радионуклидов ${ }^{137} \mathrm{Cs}$ в организме детей Иванковского и Полесского районов Киевской области Украины спустя 30 лет после аварии на Чернобыльской атомной электростанции. Науково-практичний збірник «Чорнобиль: екологія і здоров'я». Вип. 8. Іванків: Пу Координаційний аналітичний центр «Екологія і здоров'я»; Дніпро: Середняк Т.К., 2019. C. 4-10.

9. Дубовая Н.Ф.,

Бандажевский Ю.И.

Особенности домашнего питания сельских детей, проживающих на радиоактивно загрязненных территориях, в 
постчернобыльский период. Науково-практичний збірник «Чорнобиль: екологія і здоров'я». Вип. 8. Іванків: ПУ Координаційний аналітичний центр «Екологія і здоров'я»; Дніпро: Середняк Т.К., 2019. C. 23-30.

10. Bandazhevsky Yu.I. Chronic Cs-137 incorporation in children's organs. Swiss Medical Weekly. 2003. Vol. 133. P. 488-490.

11. Бандажевский Ю.И., Дубовая Н.Ф., Бандажевская Г.С., Кадун О.Н., Переплетчиков А.М., Жербо Л. Чернобыль, 25 лет: инкорпорированные радионуклиды Cs-137 и здоровье людей / под ред. Ю.И. Бандажевского. Киев : Координационный аналитический центр «Экология и здоровье», 2011. 156 с.

REFERENCES

1. 20 rokiv Chornobylskoi katastrofy. Pohliad u maibutnie : Natsionalna dopovid Ukrainy [20 Years of the Chornobyl Disaster. Looking to the Future: The National Report of Ukraine]. Kyiv : Atika ; 2006 : 232 p. (in Ukrainian).

2. Radiatsionnyy monitoring oblucheniya naseleniya $v$ otdalennyy period posle avarii na Chernobylskoy AES.

Rabochiye materialy TS proekt RER / 9/074 «Strategiya dolgosrochnykh mer zashchity i monitoring oblucheniya naseleniya selskikh territoriy, podvergshikhsya vozdeystviyu Chernobylskoy avarii»» [Radiation Monitoring of the Population Exposure in the Remote Period after the Accident at the Chernobyl NPP. Proceedings of the TS Project RER/9/074 Long-Term Countermeasure Strategies and Monitoring of Human Exposure in Rural Areas Affected the Chernobyl Accident]. Vienna ; 2007 : 119 p. (in Russian).

3. Perevoznikov O.N., Litvinets L.A., Yakovleva G.N. andVasilenko V.V.

Metodicheskiye rekomendatsii po provedeniyu izmereniy s ispolzovaniyem schetchikov izlucheniya cheloveka pri dozimetricheskoy pasportizatsii naselennykh punktov Ukrainy [Guidelines for the Measurements Using the Human Radiation Counters at the Dosimetric Certification of Settlements of Ukraine]. Kiev 1995. 25 p. (in Russian).

4. Nechaiev S.Yu., Vasylenko V.V., Perevoznikov O.M., Rubel N.F. andPikhta V.O. Monitorynh doz vnutrishnoho oprominennia naselennia na piznomu etapi avarii na ChAES z vykorystanniam lichylnykiv vyprominiuvannia liudyny : metodychni rekomendatsii [Monitoring of the Doses of the Internal Radiation of the Population at a Late Stage of the Accident at the ChNPP Using the Counters of Human Radiation: Guidelines]. Kyiv; 2010 : 24 p. (in Ukrainian).

5. Vasylenko V.V., Masiuk S.V., Ivanova O.M., Pikta V.O., Boiko Z.N., Chepurnyi M.I. et al. Rezultaty LVL-vymiriuvan, provedenykh na radioaktyvno zabrudnenykh terytoriiakh Ukrainy u 1986-2014. (reviziia ta analiz). [Results of WBC Measurements were Made at Radioactively Contaminated Territories of Ukraine in 19862014 (Revision and Analysis)]. In : Problemy radiatsiinoi medytsyny ta radiobiolohii [Problems of Radiation Medicine and Radiobiology]. Kyiv ; 2018 ; 23 :120-137. doi: 10.33145/2304_8336_2018_23 120138 (in Ukrainiañ).

6. Kadun O.N. Ivankov and Polessky Districts Implementation of SocioMedical Project of the European Commission «Health and Environmental Programs round the Chernobyl Exclusion Zone». In : Yu.I. Bandazhevsky (Ed.). Collection of Scientific and Practical Articles «Chernobyl: Ecology and Health». Issue 6. Ivankiv, Ukraine: PI Coordination and Analytical Center «Ecology and Health».Dnipro:

Seredniak T.K. : 2017 : 4-11.

7. Pro zatverdzhennia form pervynnoi oblikovoi dokumentatsii ta Instruktsii shchodo yikh zapovnennia, shcho vykorystovuiutsia u zakladakh okhorony zdorovia nezalezhno vid formy vlasnosti ta pidporiadkuvannia : Nakaz MOZ Ukrainy 14 liutoho 2012 r. № 110. [On the Approval of the Forms of Primary Accounting Records and Instructions on their Completion, Used in Health Care Institutions Regardless of
Ownership and Subordination: Order of the Ministry of Health of Ukraine, 14 February 2012, № 110]. URL: https://zakon. rada.gov.ua/laws/show/z066112 (in Ukrainian).

8. Bandazhevskiy Yu.I., Dubovaya N.F. and Kadun O.N. Vozrastnyye osobennosti soderzhaniya radionuklidov 137Cs v organizme detey Ivankovskogo i Polesskogo rayonov Kiyevskoy oblasti Ukrainy spustya 30 let posle avarii na Chernobylskoy atomnoy elektrostantsii [Age-Related Features of ${ }^{137} \mathrm{Cs}$ Radionuclides' Content in the Organism of the Children of Ivankiv and Polissia Raions of Kiev oblast of Ukraine in 30 Years after the Accident at the Chernobyl Nuclear Power Plant]. In : Chornobyl: ekolohiia i zdorovia : nauk. -prakt. zb. [Chornobyl: Ecology and Health : Sci.-Pract. Coll.]. Ivankiv, Ukraine ; Дніпро ; 2019 ; 8 : 410 (in Russian).

9. Dubovaya N.F. and Bandazhevskiy Yu.I. Osobennosti domashnego pitaniya selskikh detey. prozhivayushchikh na radioaktivno zagryaznennykh territoriyakh. v postchernobylskiy period [Features of Home Nutrition of Rural Children Residing in Radioactively Contaminated Territories in the Post-Chernobyl Period]. In : Chornobyl: ekolohiia i zdorovia : nauk. -prakt. zb. [Chornobyl: Ecology and Health : Sci.-Pract. Coll.]. Ivankiv, Ukraine ; Дніпро ; 2019 ; 8 : 23-30

(in Russian).

10. Bandazhevsky Yu.I. Chronic Cs-137 Incorporation in Children's Organs.

SwissMedicalWeekly. 2003 ; 133 : 488-490(in Russian).

11. Bandazhevskiy Yu.l., Dubovaya N.F., Bandazhevskaya G.S., Kadun O.N., Perepletchikov A.M. and Zherbo L. Chernobyl, 25 let: inkorporirovannyye radionuklidy Cs-137 i zdorovye lyudey

[Chernobyl, 25 Years: Incorporated Radionuclides Cs-137 and Human Health] Bandazhevskiy Yu.I. (ed.). Kiev : Koordinatsionno-analiticheskiy tsentr «Ekologiya I zdorovie»; 2011 : 156 p. (in Russian).

Надійшла до редакції 14.02.2020 